\title{
GEOCHEMICAL MONITORING OF INDUSTRIAL CENTER FOR DEVELOPMENT OF RECREATIONAL AREAS (ON THE EXAMPLE OF KHROMTAU-DON INDUSTRIAL HUB, KAZAKHSTAN)
}

\author{
Aidana BEKETOVA* \\ L.N. Gumilyov Eurasian National University, Faculty of Natural Sciences, Satpayev \\ Str., 2, 010008 Nur-Sultan, Republic of Kazakhstan, e-mail: atbeketova@mail.ru

\section{Zharas BERDENOV} \\ L.N. Gumilyov Eurasian National University, Faculty of Natural Sciences, atpayev \\ Str., 2, 010008 Nur-Sultan, Republic of Kazakhstan, e-mail: berdenov-z@mail.ru
}

\section{Gulshat ATAEVA}

K. Zhubanov Aktobe Regional State University, Department of Ecology, A. Moldagulova Prospect, 34, 030000 Aktobe, Republic of Kazakhstan, e-mail: beskurek@mail.ru

\author{
Ruslan SAFAROV \\ L.N. Gumilyov Eurasian National University, Faculty of Natural Sciences, \\ Satpayev Str., 2, 010008 Nur-Sultan, Republic of Kazakhstan, e-mail: ruslanbox@yandex.ru
}

\section{Zhanat SHOMANOVA}

Pavlodar state pedagogical university, Department of Geography and Chemistry, Mira Str., 6o, 14000o Pavlodar, Republic of Kazakhstan, e-mail: zshoman@yandex.ru

\section{Grigore Vasile HERMAN}

University of Oradea, Department of Geography, Tourism and Territorial Planning, Universității Street, 1, 410087, Oradea, Romania, e-mail: grigoreherman@yahoo.com

Citation: Beketova A., Berdenov Z., Mendybayev E., Safarov R., Shomanova Zh. \& Herman G.V. (2019). GEOCHEMICAL MONITORING OF INDUSTRIAL CENTER FOR DEVELOPMENT OF RECREATIONAL AREAS (ON THE EXAMPLE OF KHROMTAU-DON INDUSTRIAL HUB, KAZAKHSTAN). GeoJournal of Tourism and Geosites, 27(4), 1449-1463. https://doi.org/10.30892/gtg.27428-447

\begin{abstract}
Landscape-geochemical assessment of the industrial areas is of particular interest. This paper describes the microelement composition of soils, investigates hydrochemical composition of surface waters and vegetation of the territory. A landscape-geochemical analysis of the Khromtau industrial zone was carried out. The article includes results of studying of the patterns of the profile distribution of the morphological, physico-chemical properties of soils and their transformation under the influence of the mining industry and urban loads. The study reveals main types of rearrangements of the ecological and geochemical structure of soil profiles, which sharply differ from the background soils of the region. During field research, key
\end{abstract}

\footnotetext{
* Corresponding author
} 
Aidana BEKETOVA, Zharas BERDENOV, Gulshat ATAEVA,

Ruslan SAFAROV, Zhanat SHOMANOVA, Grigore HERMAN

areas were laid. In the key areas, soil pits were laid for sampling soil from various horizons, for subsequent chemical analysis of the constituent components, and vegetation was selected for chemical analysis. Geoenvironmental analysis allows scientific justifying creation of technogenic reservations as a basis for protection of recreational areas. The work contains conceptual and methodological approaches to ensuring geo-ecological assessment of geosystems. The analysis of the interaction of the natural, economic, social subsystems and control systems with modern geosystems, based on the ecosystem services, provided by natural subsystem demanded by society and economy. A model of technogenic geosystem and a series of the indicators reflecting properties, quantitative and qualitative features of each block of subsystems has been developed. Structural variations which arise in geosystem as a result of anthropogenous transformation lets to establish quality of technogenic geosystem and to rank them from steadily functioning to the actively degrading.

Key words: technogenic load, soil, soil profile, heavy metals, geochemical analysis

\section{INTRODUCTION}

Pollution with heavy metals has the most technogenic load on soils of industrial cities because fast self-purification from metal pollution to the level required for hygienic and environmental safety is complicated and in many cases impossible (Berdenov, 2014).

Industrial urbanization has special role in pollution of soil cover. Urbanization is a social phenomenon and geoecological problems are universal, general scientific. They are of great practical importance. We can talk about environmentally friendly situation in industrial hubs only when the science will consider problems from the positions of human life support and rational «Human-Nature» relationships (Dubrovskaya, 2012; Shomanova et al., 2017; Romocea et al., 2018). Urban areas are a special type of ecological systems when natural components change significantly and often irreversibly under various intensive anthropogenic loads.

Despite fundamental reconstruction of the most important properties according to a number of leading researchers (Stroganova et al., 1997, pp. 234-275) urban soils are recognized as the basic constituent of urbogeosystem, that implements the most important ecological and economical functions and determines living conditions in city.

\section{MATERIALS AND METHODS}

The study area is located between the southern spurs of the Urals and the northern ridges of Mugodzhary. The steppe here is hilly, the maximum height does not exceed 490 meters. The territory is located in the Ory-Ilek interfluve, refers to the basin of the Ural River. The considered territory is located in the zone of dry steppes. This zone is characterized by the spread of dark chestnut soils. Soil-forming rocks here are dark brown sandy loam, hard with rare interlayers of loam and sand. The territory of the object is located in the subzone of dark chestnut soils. According to the report (Technical report, 2017) about engineering and geological surveys the site consists of soil-vegetation layer loamy, brown with plant roots, thickness - $0.2 \mathrm{~m}$; sandy loam - light-brown, calcareous, solid, thickness - 1.8-2.0 m; sands of medium size - gray, medium density, thickness - 2.0 - $2.3 \mathrm{~m}$. The complexity ща structural-tectonic structure of the South Ural causes lithological-mineralogical diversity, presence of the most important stratigraphic sections, wide exhibition of karst processes and others (Kotlyar et al., 2013 ). Mining in the region brings a serious danger for safety of the objects of geological heritage (Badiali 
et al., 2018). Our research shows necessity of developing of unified interregional concept of saving of the objects of geological and geomorphological heritage of Ural and Mugodzhars. One of the research directions is geo-environmental analysis of methodological approaches, which is used for forecasting of technogenic situation in the industrial region and for protection of objects of geological heritage (Theng et al., 2014).

In the Aktobe region there are 19 geological nature memorials. 10 of them are placed within the Ural-Mugodzhar mountains, where mining industry is intensively developed. Some of the enterprises are of international significance, amongst them is global stratotype ща the board between coal and perm systems "Aidarlyasha river valley". The necessary of saving of objects of geological heritage is obvious, that is approved by scientific researches and by documents of government of the Republic of Kazakhstan (Pavleichik, 2015). On the studied territory the structure of geological nature memorials is different. There geomorphological component of the object becomes secondary, but stratigraphical and paleontological worth is more important.

In addition to well known geological nature memorials of republican significance, other 14 objects of geological heritage of Aktobe region (Kazakhstan) are waiting for getting an official status. A vivid example of geological nature memorial is necropolis «Oysylkara» standing 15 kilometers from Khromtau city (Figure 1).

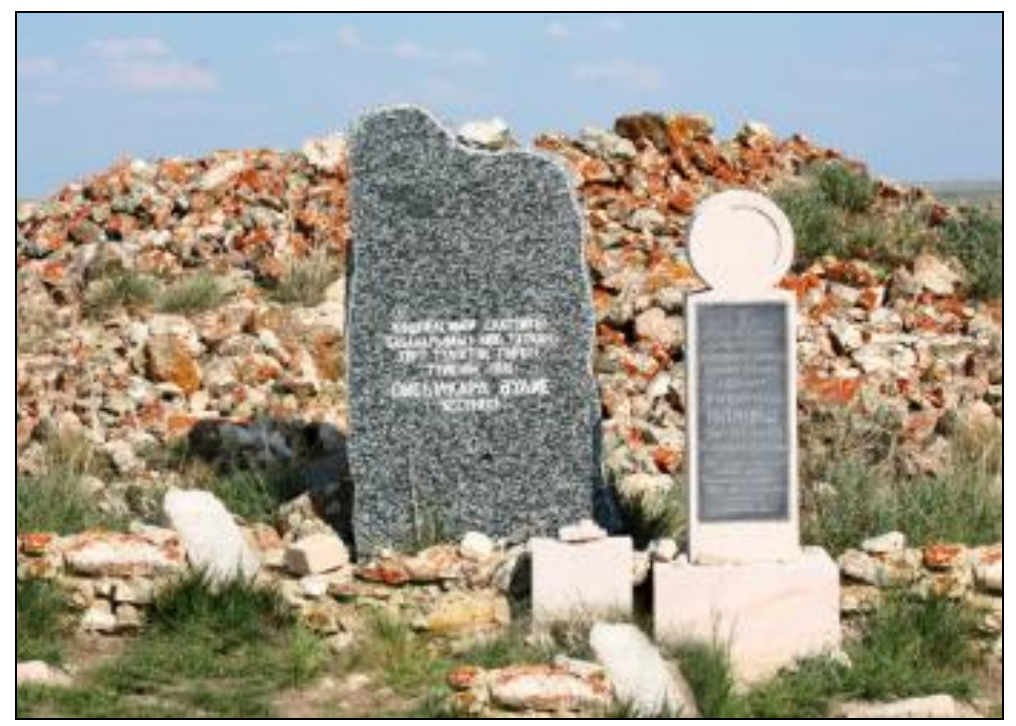

Figure 1. Oysylkara ancient memorial

The memorial is named after spirit - protector of camels, and keeper of camels herd. The necropolis dates from the 18th - beginning of the 2oth centuries, representing a cemetery with an area of 100 by 170 meters. In the center of the cemetery there is a high mound of stones piled round. At this place there is a monument of iron, painted in green. It is believed that it was here that Saint Oysylkar, who was a real historical figure, was buried. Oysylkara was a very religious person, distributing the hadiths of the prophet Muhammad. Unfortunately, the mechanism for giving environmental status to geological objects is not without difficulties. One of them is a complex and lengthy process of preparing the necessary documentation. This leads to the fact that many already recognized objects of natural heritage are not yet reflected in the schemes of territorial 
Aidana BEKETOVA, Zharas BERDENOV, Gulshat ATAEVA,

Ruslan SAFAROV, Zhanat SHOMANOVA, Grigore HERMAN

planning (land use), are not put on cadastral registration, passports and protective obligations are not drawn up on them. This may entail the loss of the value or integrity of natural objects. So, as a result of mining, the ancient Alabas volcano ("Shuyl-Dak paleovolcanic region"), the original karst landscape and the southernmost gypsum caves of the Urals, the reef valuable in stratigraphic and paleontological terms ("Algal reef limestones of the Lower Perm age of Aktastinsky reef" are partially destroyed).

Deposits of chromium, copper and nickel are the main technogenic sources and wealth of studied area. The second by quantity in the world deposit of chromite ore, extraction of which is carried out by both mining and quarrying (Figure 2), is placed here. Many environmentally hazardous objects are located on area of studied territory. In the structure of industrial production of the city mining industry holds $94.3 \%$, manufacturing industry - 3.6\% (LLP «Khromtau brick factory», JSC «Ceramics», LLP «Aktyubinsk bakery factory»), production and distribution of heat, gas and water $-2.1 \%$ (Program, 2012; Shomanova et al., 2018). The main city-forming enterprise of the industrial hub is Donskoy Ore Mining and Processing Plant - a branch of T Kazkhrom MNC, which specializes in the extraction and enrichment of chrome ore. The enterprise extracts practically the entire amount of chrome ore in Kazakhstan. Every third family living in Khromtau is related with the city-forming enterprise. $68.4 \%$ of economically active city population work at Donskoy Ore Mining and Processing Plant. Anthropogenic objects quarries for extraction of chromium, nickel, copper and other - call special attention. Under this powerful technogenic load soils acquire new complex of properties and regimes determining abilities to effectively perform various environmental functions.

Recent geoecological researches in the region were mainly focused on studying of morphogenesis and pollution of water bodies adjacent to the territory (Khomyakov, 2011; Koshim et al., 2015). However, aspects of formation and current condition of soil cover remain underexplored. There is no information about character of intraprofile distribution of the most important soil properties determining processes of transformation, accumulation and outflow of technogenic substances in soil stratum.

The analysis of the geosystem functioning intensity degree of intensive technogenic pollution zones is created at the first stage of geo - ecological assessment. For the realization of this task we had to make a landscape map of the study area (Figure 2) (Berdenov et al., 2016). Conducting open-cast mining in scale leads to the greatest disturbances to the surface of the earth. In this case, the soil cover is destroyed up to the geological foundation, vegetation is destroyed, and the hydrological regime as a whole is violated. A man-made dump-quarry landscape specific to open mining is formed.

The technogenic geosystem consists of several subsystems, and the main of them according to time of formation and importance is - natural one. From the position of geo-ecological analysis natural ecosystem (landscape) is characterized by definite geoecological services and resources, which it provides to the society (this terminology is used in the fundamental work prepared according to UN International program "An assessment of ecosystems at a turn of the millennia»). This concept included various natural resources or properties, useful to the person, thanks to which in general there is possible an activity of society and the certain person as a species (Berdenov et al., 2017).

The application of the technogenic geosystem model for the geoecological assessment of specific geosystems requires indicators that describe individual components of nature, their properties and processes (soil, vegetation cover) (Kabiyev et al., 2018). Collection of information, its processing and formalization are necessary procedures for computer systematization of extensive volumes of information and creation of classifications of technogenic geosystems. As a part of natural subgeosystem it 
Geochemical monitoring of industrial center for development of recreational areas (on the example of Khromtau-don industrial hub, Kazakhstan)

is a series of indicators of a litogenny basis of a landscape (the morphological structure of a surface, the soil-forming material, etc.) the hydro climatic and biogenous indicators. They determine the natural and resource potential (NRP) of geosystem, on a basis by which series of the practical actions necessary for improvement of environment and further use of natural and resource capacity of the region are developed (Berdenov et al., 2016). The main agents at transformation and violation of interconnections in landscapes are the factors of a production activity: industries, development of minerals, residential systems. The results of functioning of production objects, exploration of natural resources can be agents of such types (for example, emissions of waste, volume of the biomass alienated with a crop, density of infrastructure networks) and others.

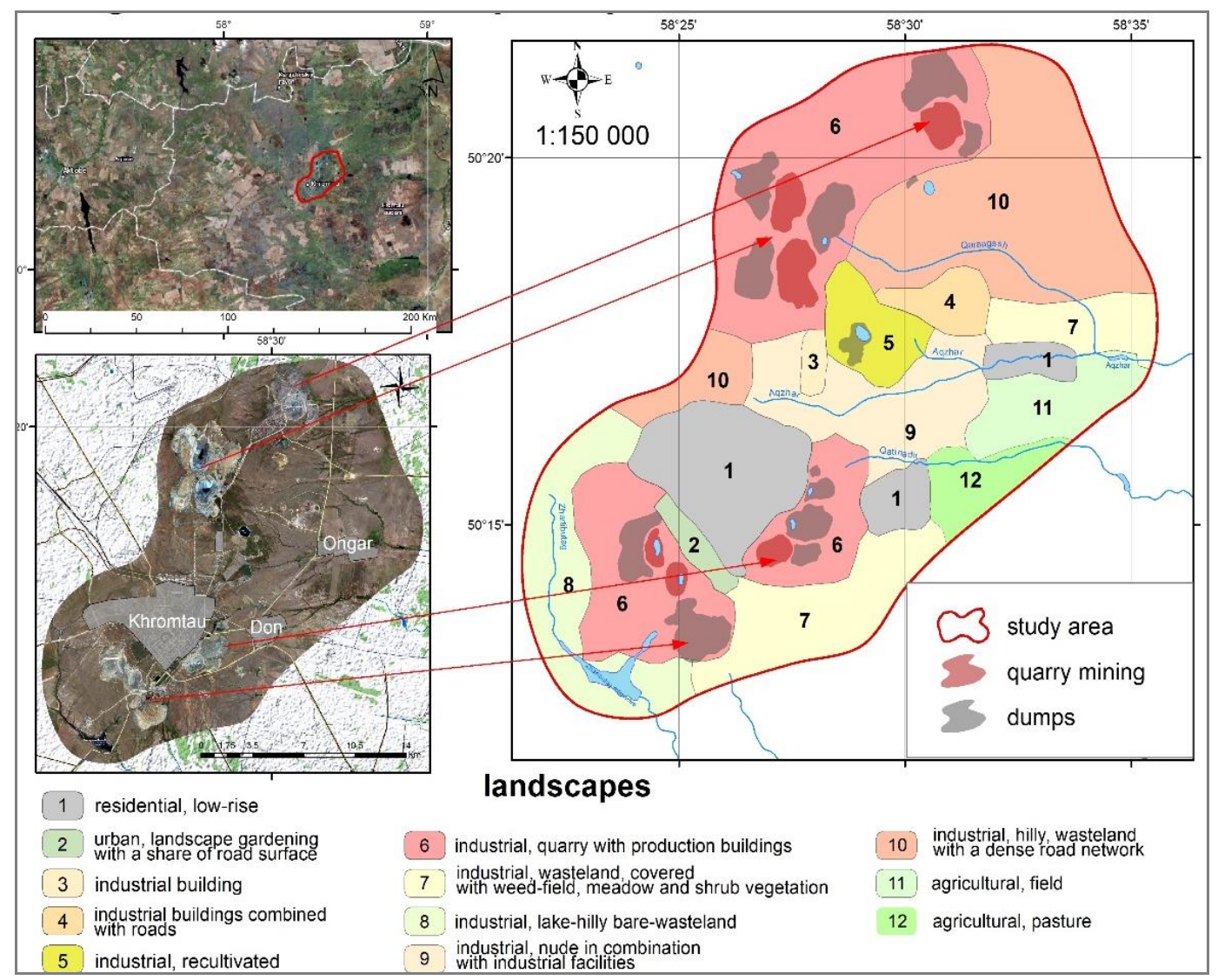

Figure 2. Map of modern landscapes of the study area (Khromtau industrial site)

It should also be borne in mind that, due to the great public outcry, today there is an increased interest of people both in the environmental problem as a whole and in specific environmental issues related to individual regions (Gozner et al., 2017, Ilieş et al., 2017; Ilieş et al., 2018; Lincu et al., 2018, Herman et al., 2019). The objective study of the structure and dynamics of landscapes industrial zones is particularly relevant in connection with the continued growth and expansion of the production of nonferrous metallurgy, which determines the special significance of environmental risk assessment. Inevitably, with the growth of mancaused impact, geosystems structure changes occur, including a change in their chemical 
parameters under the influence of mechanical disturbances and pollution. Therefore, knowledge of the geochemical characteristics and chemical composition of the components of landscapes, their metabolism is necessary to support the effective implementation and environmental monitoring industrial regions (Perelman \& Kasimov, 1999).

To assess the degree of anthropogenic impact on the landscapes into account the parameters of a violation of medium components were evaluated geochemical changes. Finally got the classification model, the parameters of which are linked to certain anthropogenic load, differ in kind and degree of exposure (Table 1). To determine the degree of technogenic loading and transformation of all types were introduced ballroom expert assessment showing the relative degree of anthropogenic transformation. For this purpose, the normalized indicators of anthropogenic pressures on ecosystems (Vaganova \& Kovalchuk, 2012; Jasinski, 2000). The following rules limit the use of environmental landscapes allow us to rank the territory according to the degree of technogenic load on landscapes, and, moreover, reasonably use the results to optimize the structure of nature.

Table 1. Scale of valuation indicators of technogenic pressures on landscapes

\begin{tabular}{|c|c|c|c|c|c|}
\hline \multirow{2}{*}{ Index } & \multicolumn{5}{|c|}{ Mark } \\
\hline & $\mathrm{O}$ & 1 & 2 & 3 & 4 \\
\hline Area of settlements, \% & not & $\leq 10$ & $1-3$ & $3-7$ & $\geq 10$ \\
\hline Population density, persons $/ \mathrm{km}^{2}$ & not & $\leq 10$ & $10-20$ & $20-30$ & $\geq 30$ \\
\hline Transportation load $\mathrm{km} / \mathrm{km}^{2}$ & not & $\leq 0.1$ & $0.1-0.2$ & $0.2-0.3$ & $\geq 0.3$ \\
\hline The area of technogenic formations, \% & not & $\leq 0.5$ & $0.5^{-1}$ & $1-3$ & $\geq 3$ \\
\hline The area of arable land, \% & not & $\leq 10$ & $10-40$ & $40-60$ & $\geq 60$ \\
\hline The area of pastures, \% & not & $\leq 20$ & $20-40$ & $40-70$ & $\geq 70$ \\
\hline
\end{tabular}

In assessing the degree of anthropogenic impact on the ecosystem of the quantitative indicators for each parameter were translated into scores (o to 4), which are then summed. The result of the summation is an integral indicator (U), the proposed K.M. Petrov (Petrov, 1998), the formula (1):

$$
U=\frac{1}{\mathrm{n}} \sum x_{\mathrm{i}} k_{\mathrm{i}}
$$

where

$n$ - the number of factors;

$x_{i}$ - Scoping i factor;

$k_{i}$ - i weighting factor.

The weights are established by experts, based on the ranking of indicators on the extent of human impact on geosystems. Indicators characterizing these factors formed the basis of the zoning (ranking) of the study area on the degree of technogenic impact. Upon receipt of the integral indicator (U), the following graduation degrees of impact on landscapes: 1-2 - mid impact; 2-3 - intense, 3-4 - extevely.

\section{RESULTS DISCUSSIONS}

Solid and liquid wastes that accumulate in open storage facilities, landfills, chrome dumps also affect the environment. Soils, surface watercourses are polluted due to the flushing of tailings by melt and rain waters. The dissected relief of Khromtau, characteristic of the industrial territory, slopes towards the Akzhar, Katynadyr and Zharlybulak rivers contribute to the discharge of water into the basin. 
Relief changes are facilitated by field development. Since 2000, waste rock has been used in the construction of roads to fill the treatment space of worked horizons and closed mines, pits, ditches. The landscapes in which mining enterprises are located are characterized by increased atmospheric air pollution as a result of the spread of fine-grained waste rock. Denudation of overburden in dumps, mines, quarries and the subsequent migration of the chemical elements contained in them with the formation of secondary dispersion areas are also an integral part of technogenesis. During storage of rocks extracted from the massif during the excavation of mines, as well as during overburden operations at quarries and open pits, dump embankments are formed.

Dump embankments can be diverse in scale and shape. Mining quarries and dumps in most cases are lifeless territories. Erosion processes disable extensive areas, contribute to the accumulation of material at the foot of the slopes (Ungureanu et al., 2015). Around the city of Khromtau there are several dumps on which overburden is stored in several tiers with a height of more than $20 \mathrm{~m}$. The resulting artificial rugged relief is a combination of high embankments and shallow depressions. The slopes of the dumps are riddled with ravines. When we study the surface water in the area (r. Akzhar, r. Katynadyr and r. Zharlybulak) set a wide range of chemical elements in aquatic systems and the estimation of water pollution to sanitary protection zone, and after the sanitary protection zone. Studied in detail questions of technogenic pollution of surface waters and r. Akzhar, r. Katynadyr salts, heavy metals and other pollutants Table 2.

Table 2. The results of chemical analyzes of trial (average for 2019)

\begin{tabular}{|l|c|c|c|}
\hline \multicolumn{1}{|c|}{$\begin{array}{c}\text { Appellations } \\
\text { Substances }(\mathrm{mg} / \mathrm{l})\end{array}$} & $\begin{array}{c}\text { Average value in the } \\
\text { river Akzhar }\end{array}$ & $\begin{array}{c}\text { Average value in the } \\
\text { river Katynadyr }\end{array}$ & $\begin{array}{c}\text { Average value in the } \\
\text { river Zharlybulak }\end{array}$ \\
\hline Turbidity & 3.5 & 4.4 & 1.42 \\
\hline Colority & 28.3 & 45 & 27 \\
\hline Oxidability & 3.5 & 3.7 & 3.1 \\
\hline $\mathrm{pH}$ & 8.1 & 8.3 & 7.7 \\
\hline Polyphosphate & 0.04 & 0.02 & 0.01 \\
\hline Total hardness & 7.1 & 7.3 & 5.5 \\
\hline Ammonia & 0.03 & - & 0.1 \\
\hline Nitrate & 38 & 43 & 36 \\
\hline The chlorides & 142 & 127 & 107 \\
\hline Sulphates & 130 & 189 & 141 \\
\hline Copper $\left(\mathrm{Cu}^{2+}\right)$ & 0.59 & 0.72 & 0.21 \\
\hline Manganese $\left(\mathrm{Mg}^{2+}\right)$ & $0.07-0.01$ & $0.083-0.03$ & $0.03-0.04$ \\
\hline Chromium $\left(\mathrm{Cr}^{3+}, \mathrm{Cr}^{6+}\right)$ & 0.32 & 0.89 & 0.65 \\
\hline
\end{tabular}

Analysis of trace-element composition of surface waters shows that the concentration of heavy metals in them exceeds the background value several times in the river Akzhar and in the river Katynadyr water and have the highest degree of concentration in soluble form. This is apparently due to the weather conditions in spring and autumn periods of observation. In the period of stabilization of the water regime of the rivers and the lack of strong surface flow changes in the composition of trace-element concentrations was observed. This suggests that the main factor influencing the change in concentrations of trace elements in surface watercourses draining industrial and 
Aidana BEKETOVA, Zharas BERDENOV, Gulshat ATAEVA, Ruslan SAFAROV, Zhanat SHOMANOVA, Grigore HERMAN

residential zone, is runoff from anthropogenic areas (Kasimov, 1995). Thus, condition of surface waters in the limits of the industrial area does not suppose development of the recreation. The fact is compensed by the presence in the region of two water reservoirs. Profound changes in the territory of the agglomeration undergo soil. The main feature of these changes is the change in soil-forming processes, soil functioning.

The process of forming a natural pedomass the city changed to $70-80 \%$, no mortmass, reducing the additional application of nutrients, reducing the percentage of longitudinal substances. Under the influence of technogenic soils in the study region reduced bulk density of the natural soil, changed the structure of the soil horizons, increasing the amount of fine particles is their intensive removal of the soil profile, altered redox, acid-alkaline conditions and formed new geochemical barriers, not typical for zonal soil properties. The relief structure is undergoing major changes.

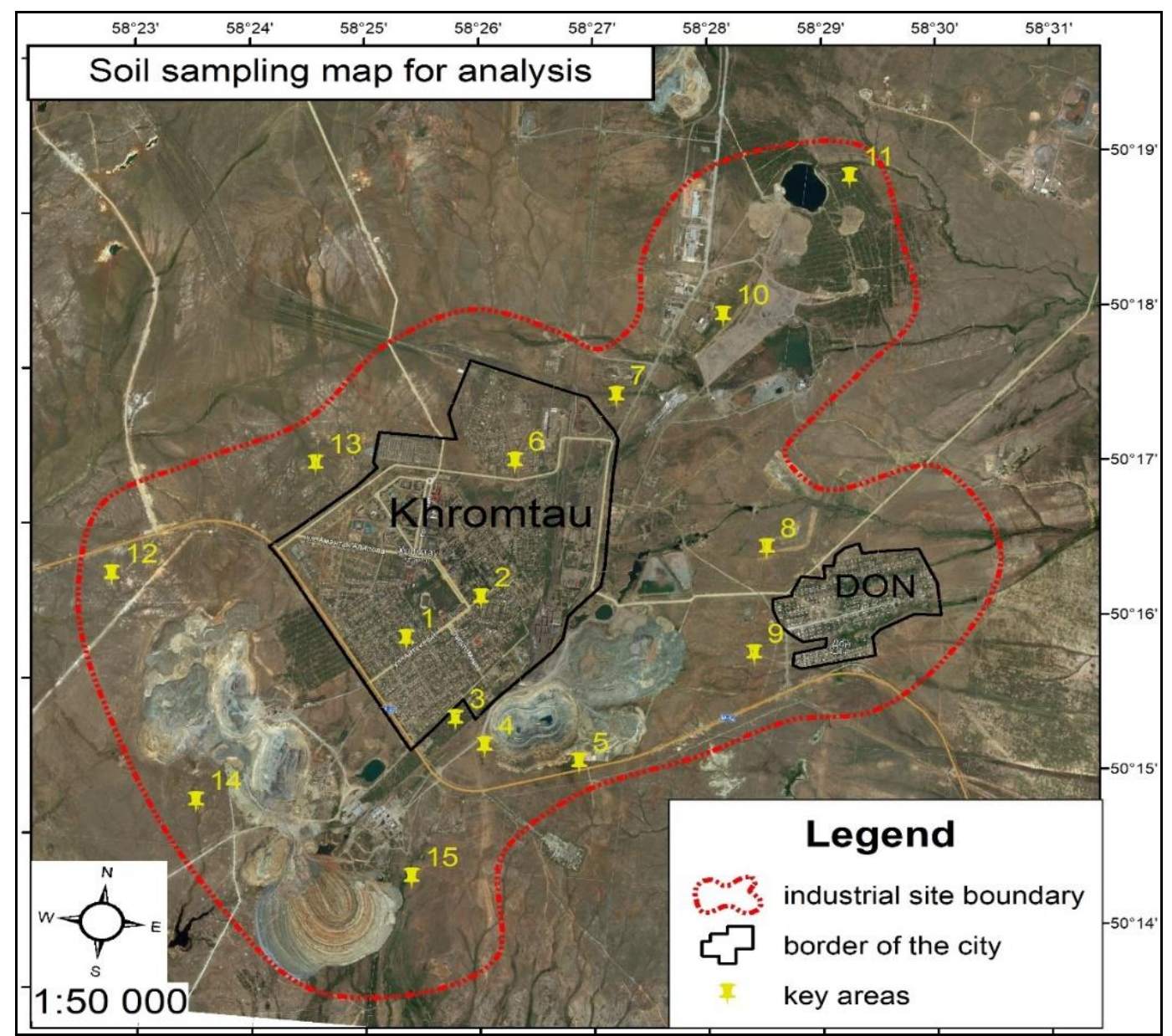

Figure 3. Map of sampling on soil pits within industrial hub

So in southern and northern parts of the city of Khromtau changed the percentage of nutrients, increased decay products of chromium, copper, manganese. Soil cover of industrial hub is a specific object of research. At initial stage on the basis of 
complex analysis of archive materials we selected key sites (Figure 3) reflecting variety of economical use of studied the area. During the field study (in summer, 2019) we laid out 15 full-profile open-pit mines, 10 by-pits and 4 half-digs, performed morphological description of profiles and soil sampling with further analysis by next parameters: granulometric texture, $\mathrm{pH}$, humus level (by Tyurin), exchangeable base status, content of ready soluble salts in water extract, content of heavy metals by GOST 22036-2014.

We used the method of biotests for assessment of general soil pollution degree (Mendybayev et al., 2015; Berdenov \& Dzhanaleeva, 2015). As reference standards, we used soil samples - southern black soil and dark chestnut soil from long-fallow lands of southeast part of Khromtau district near Kyzylzhar village. During the study it was defined that morphology of these soil groups even at minimal degree of disruption differs from zonal soils in variety of significant peculiarities. Chemically polluted soils are widely distributed ( $80 \%$ of territory). In building areas of inhabited localities soil cover becomes discrete as a result of architectural reclaiming. Soil profiles of open not sealed sites are characterized by absence of natural genetic horizons and represent artificial constructions of layers, which are consist of silty substrate of different thickness and quality with impurities of dumps, household and industrial waste.

Table 3. Results of chemical analyses of some samples of soil, 2019

\begin{tabular}{|c|c|c|c|c|c|c|c|c|}
\hline \multirow{2}{*}{$\begin{array}{c}\text { № } \\
\text { Profile of } \\
\text { key site }\end{array}$} & \multirow[b]{2}{*}{ Horizon } & \multirow{2}{*}{$\begin{array}{c}\text { Stratification } \\
\text { depth, cm }\end{array}$} & \multirow[b]{2}{*}{$\mathrm{pH}$} & \multirow[b]{2}{*}{ Humus, \% } & \multicolumn{4}{|c|}{ Absorbed bases, mg-eq } \\
\hline & & & & & $\mathrm{Ca}^{+}$ & $\mathrm{Mg}^{+}$ & $\mathrm{Na}^{+}$ & $\begin{array}{c}\text { Base exchange } \\
\text { capacity }\end{array}$ \\
\hline \multicolumn{9}{|c|}{ Natural and slightly-disrupted soils } \\
\hline \multirow{3}{*}{1} & A & $0-15$ & 7.8 & 3.50 & 25.20 & 3.10 & 0.40 & 18 \\
\hline & B & $15-25$ & 8.0 & 3.10 & 28.50 & 3.80 & 0.52 & 15 \\
\hline & $\mathrm{BC}$ & $30-70$ & 7.5 & 1.05 & 22.00 & 4.50 & 0.45 & 15 \\
\hline \multirow{4}{*}{8} & A & $0-10$ & 7.5 & 4.20 & 12.20 & 0.50 & 0.30 & 20 \\
\hline & B & $15-30$ & 7.1 & 4.00 & 18.10 & 2.50 & 0.57 & 22 \\
\hline & $\mathrm{BC}$ & $30-50$ & 7.0 & 2.10 & 17.50 & 3.00 & 0.40 & 18 \\
\hline & $\mathrm{C}$ & $60-100$ & 7.4 & 0.40 & 22.70 & 1.40 & 0.45 & 22 \\
\hline \multirow{4}{*}{13} & A & $0-20$ & 7.0 & 5.10 & 12.50 & 1.90 & 0.25 & 19 \\
\hline & $\mathrm{B}$ & $20-30$ & 6.8 & 3.70 & 12.60 & 2.50 & 0.80 & 17 \\
\hline & $\mathrm{BC}$ & $30-45$ & 7.2 & 2.50 & 12.20 & 2.10 & 0.74 & 15 \\
\hline & $\mathrm{C}$ & $50-90$ & 7.8 & 1.80 & 13.10 & 3.20 & 1.00 & 20 \\
\hline \multicolumn{9}{|c|}{ Technogenic-modified soils } \\
\hline \multirow{4}{*}{4} & A & $0-15$ & 7.8 & 1.20 & 18.50 & 7.20 & 0.50 & 15 \\
\hline & $\mathrm{B}$ & $15-40$ & 8.2 & 2.20 & 18.70 & 7.40 & 0.60 & 26 \\
\hline & $\mathrm{BC}$ & $40-90$ & 8.5 & 1.00 & 17.10 & 6.60 & 0.44 & 17 \\
\hline & $\mathrm{C}$ & $90-150$ & 8.0 & 0.70 & 16.50 & 6.65 & 0.65 & 19 \\
\hline \multirow{3}{*}{14} & $\mathrm{~A}$ & $10-20$ & 7.8 & 1.20 & 18.00 & 3.40 & 1.50 & 22 \\
\hline & $\mathrm{B}$ & $20-40$ & 9.0 & 2.50 & 12.20 & 4.50 & 1.10 & 15 \\
\hline & $\mathrm{C}$ & $40-150$ & 7.5 & 0.20 & 5.80 & 2.50 & 0.85 & 15 \\
\hline \multirow{3}{*}{11} & $\mathrm{~A}$ & $5-30$ & 8.2 & 3.10 & 25.00 & 4.50 & 0.55 & 25 \\
\hline & B & $30-50$ & 8.0 & 2.55 & 26.20 & 4.90 & 0.50 & 20 \\
\hline & $\mathrm{C}$ & $50-80$ & 7.2 & 1.70 & 19.80 & 3.45 & 0.42 & 18 \\
\hline
\end{tabular}

Urbotechnosoils are characterized by maximal level of technogenic transformation, they are groups of soil-like solids assigned to industrial areas and 
transport communications. Soil texture is forming under the influence of following factors: natural, mainly litho-geomorphological and technogenic factors (subsurface rocks, open cast mines, quarry banks), which are good observed on space images of medium magnification of apparatus Landsat. Natural (convential-disrupted) soils of researched territory are characterized by dominancy of heavy and middle loamy types.

Content of clay particles in upper horizons ranges from 40 to $60 \%$, dominant fraction is large-silty (45-55\%). Profiles of anthropogenic-modified soils are characterized by significant increase of lateral and radial non-uniformity of granulometric composition due to agitation of mass of overburden grounds, maternal rock and technologic substrates. Distribution of fractions through the profiles is irregular and often multidirectional. chemical analysis results are shown in Table 3. During the study of exchange-absorption ability of soils high saturation with bases of both slightly-disrupted and technogenic-modified soils should be noted. Some increase in relative quota of sodium was revealed in technogenic-modified soils from key site №14 located along the highway. The main reason of that excess of sodium in soil horizon, evidently, is entrance of salts from maternal rocks, that leads to extension of additional technogenic salting and salinization of soils. Results of chemical analyses (Table 4) shows increased content of some heavy metals on key sites near overburden grounds and highways.

Table 4. Results of chemical analyses of samples of soil on content of heavy metals

\begin{tabular}{|c|c|c|c|c|}
\hline $\begin{array}{c}\text { No key } \\
\text { site }\end{array}$ & $\begin{array}{c}\text { Horizon, } \\
\text { stratification depth }\end{array}$ & $\begin{array}{c}\text { Concentration of } \\
\text { chromium, } \mathrm{mg} / \mathrm{kg}\end{array}$ & $\begin{array}{c}\text { Concentration of } \\
\text { lead, } \mathrm{mg} / \mathrm{kg}\end{array}$ & $\begin{array}{c}\text { Concentration of } \\
\text { cadmium, } \mathrm{mg} / \mathrm{kg}\end{array}$ \\
\hline \multirow{2}{*}{5} & $\mathrm{~A}(10-20)$ & 2.88 & 28.50 & 0.15 \\
\cline { 2 - 5 } & $\mathrm{B}(20-30)$ & 2.80 & 20.10 & - \\
\hline \multirow{2}{*}{15} & $\mathrm{~A}(5-20)$ & 3.20 & 35.50 & 0.20 \\
\cline { 2 - 5 } 10 & $\mathrm{~B}(20-50)$ & 3.80 & 15.50 & 0.06 \\
\cline { 2 - 5 } & $\mathrm{A}(10-20)$ & 1.85 & 18.50 & - \\
\hline
\end{tabular}

Estimation of gross content of metals ( $\mathrm{Pb}, \mathrm{Cr}, \mathrm{Cd})$ carried out at the Testing Laboratory LLP «RI Batysecoproject». As a result of detailed soil analysis in key areas in the city of Khromtau, we have identified the maximum permissible concentration of cadmium, lead, copper, zinc and chromium on the borders of sanitary protection zones of large industrial enterprises in the areas of major highways (Table 5).

Table 5. The upper horizon of the soil research on the content of heavy metals

\begin{tabular}{|c|c|c|c|c|c|c|c|c|c|c|}
\hline \multirow{3}{*}{$\begin{array}{l}\text { Key areas } \\
\text { of the } \\
\text { territory }\end{array}$} & \multicolumn{10}{|c|}{ The average for 2019} \\
\hline & \multicolumn{2}{|c|}{$\mathrm{Cd}$} & \multicolumn{2}{|c|}{$\mathrm{Pb}$} & \multicolumn{2}{|c|}{$\mathrm{Cu}$} & \multicolumn{2}{|c|}{$\mathrm{Cr}$} & \multicolumn{2}{|c|}{$\mathrm{Zn}$} \\
\hline & $\mathrm{mg} / \mathrm{kg}$ & QMPC & $\mathrm{mg} / \mathrm{kg}$ & QMPC & $m q / k g$ & QMPC & $m q / k g$ & QMPC & $m g / k g$ & QMPC \\
\hline №1 & 0.25 & 0.45 & 25.45 & 0.8 & 10.10 & 0.3 & 2.25 & 0.5 & 18.01 & 0.91 \\
\hline №2 & 0.07 & 0.1 & 12.01 & 0.4 & 9.72 & 0.3 & 3.31 & 0.5 & 11.20 & 0.3 \\
\hline №6 & 0.10 & 0.3 & 95.1 & 2.5 & 7.87 & 0.2 & 1.60 & 0.3 & 4.83 & 0.21 \\
\hline №7 & 0.09 & 0.2 & 11.65 & 0.5 & 10.75 & 0.35 & 2.05 & 0.3 & 8.10 & 0.30 \\
\hline №15 & 0.09 & 0.2 & 30.55 & 1.1 & 70.67 & 2.0 & 10.39 & 2.0 & 29.40 & 1.54 \\
\hline
\end{tabular}

Note: $\mathrm{Q}$ - rate of excess by MPC

Using methods of A.G. Moshkalev (1988) and N.T. Smirnov (1979), study of vegetation in the study area conducted in trial areas of $10 x 10 \mathrm{~m}^{2}$ (Moshkalev, 1988; Smirnov, 1979). To assess the technogenic impact on the vegetation cover, a herbarium was collected for laboratory analysis to recognize the heavy metals in plants: zinc (Zn), 
Geochemical monitoring of industrial center for development of recreational areas (on the example of Khromtau-don industrial hub, Kazakhstan)

cobalt (Co) and chromium (Cr). The analysis was carried out in the laboratory of the National Center for the Integrated Processing of Mineral Raw Materials of the Republic of Kazakhstan, the state research and production association of industrial ecology "Kazmekhanobr". The results of chemical analysis are shown in Table 6.

The results in table 2 show that the average concentrations of Chromium and Nickel at all selected points are higher than the MPL, which confirms the presence of a natural geochemical anomaly here. Cobalt and zinc are within normal limits.

Table 6. The results of the analysis of plant samples taken

in the study area for the content of heavy metals $(\mathrm{mg} / \mathrm{kg})$

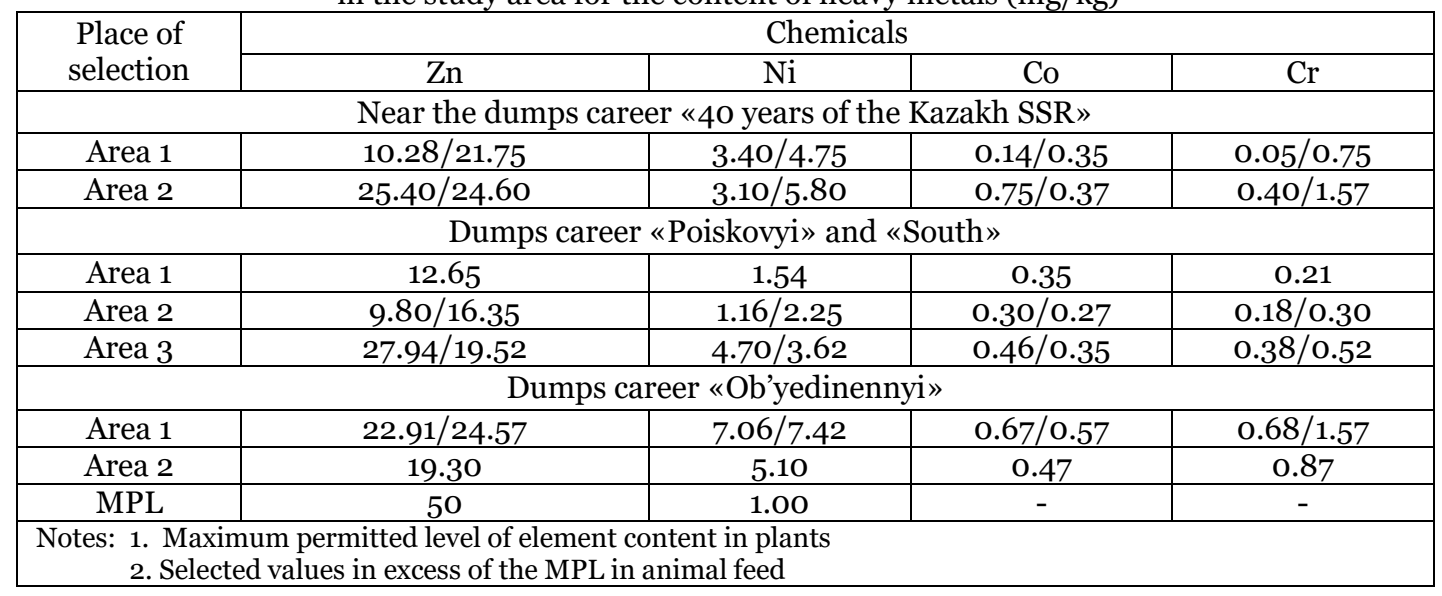

In addition to geo-ecological problems in the study area, it is also necessary to note the availability of recreational resources for the local population. These include social and recreational resources, such as a complex of various buildings and structures (Children's Entertainment Center in the center of Khromtau, Central Park with coniferous tree planting), as well as other social and cultural facilities (Gornyak Club, Turgorodok). It can be also signed natural recreational resources, which are a part of the environment, designed for mass recreation and the implementation of recreational activities. So in 1961, the Jarlybutak reservoir was built (Figure 4a), which, in addition to providing water to the central boiler house of the city of Khromtau, is also a recreational area for the local population. The reservoir is located south of the quarries Ob'edinennyj and Millionnyj. In addition, in 2014, twelve kilometers south of Khromtau, a second reservoir (the third largest in the region) was built on the Oysylkara River near the village of Abay. Its design volume is 22 million cubic meters (Figure 4b). The Oysylkar reservoir area is 4 square kilometers, the dam height is 23.5 meters, the water depth is 18 meters. Firstly, industrial water is used for agricultural purposes. Secondly, a huge water spot affected the local climate, and this is the environmental value of the project.

Especially attractive are the many ancient volcanoes that are overwhelmingly preserved as separate fragments in South Mugodzhary. It is especially valuable that all these ancient structures, unlike many others, retained their primary orientation: the dykes are vertical, the covers lie horizontally or slightly inclined. A complex of parallel dikes is perfectly represented in the coastal cliffs of the river - these are numerous vertical bodies of frozen magma, which rose from the depths of the mantle and filled the opening cracks of the lithosphere. They are composed of full-crystalline basalts - the socalled dolerites. Dikes (from the English dike - stone wall) are vertical plates (0.1-3 m 
thick) of the frozen mantle basaltic melt, which was embedded in the opening axial crack of the sea basin. The length of individual dikes does not exceed several tens of meters, however, they replace one another, creating the impression of infinitely elongated bodies (Figure 4c, d). Dykes can be traced in the submeridional direction far beyond the borders of Kazakhstan along the entire Urals as traces of the Devonian ocean. Thus, the Khromtau and Shuyldak paleovolcanic region (Southern Mugodzhary) is already the site of numerous scientific research and professional excursions.

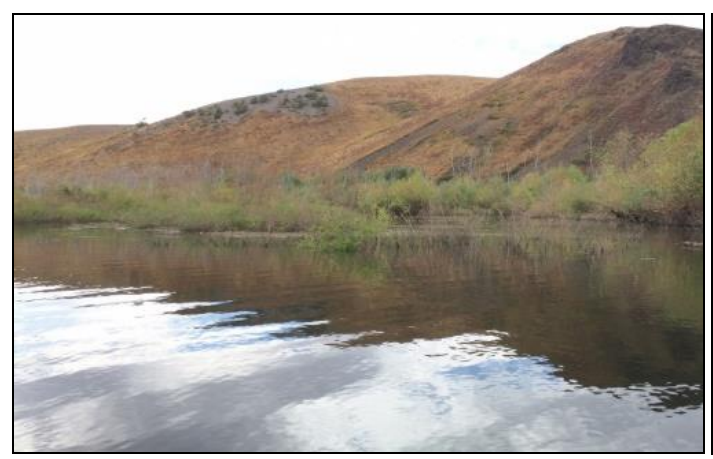

$\mathbf{a}$

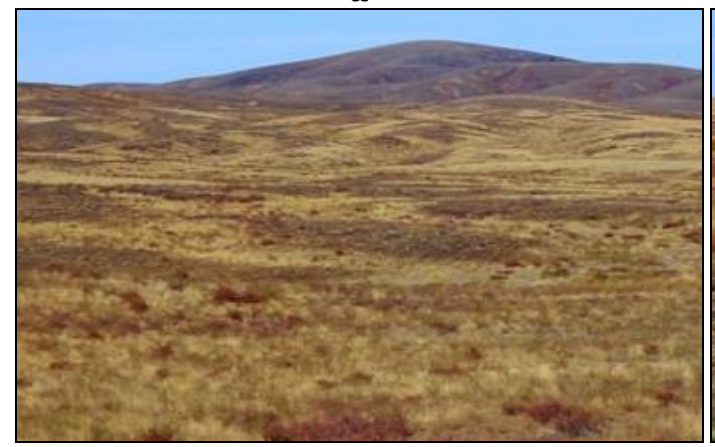

c

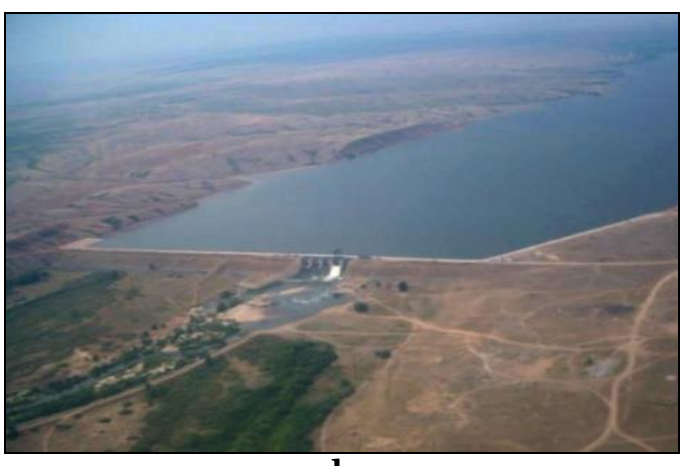

b

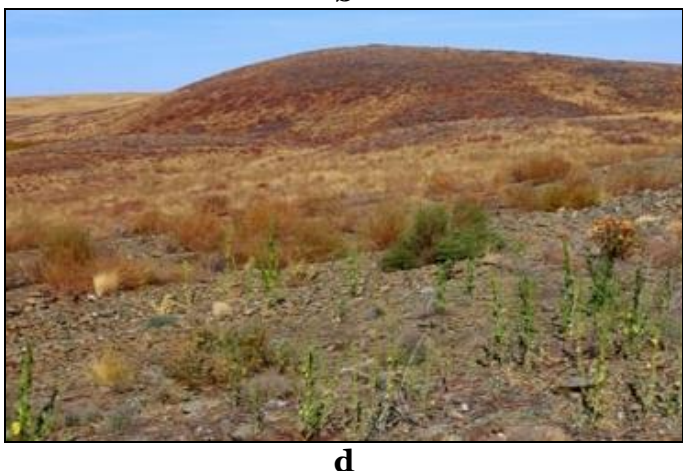

Figure 4. Recreational resources of studied territory

Dangerous for their toxic properties, are non-naturally occurring compounds such chemical elements as zinc, copper, arsenic, chromium, nickel and others. Almost all of them were found in the city. The highest concentration in the South part of the study area that is home to industrial enterprises' development, as well as intense vehicular traffic (Ramazanova et al., 2019). When the territorial characteristics of heavy metals anomalies, conducted a multi-element anomaly detection of heavy metals, determination of the concentration on the hazard classes and the total pollution of soils identified chemical elements so identified area of total pollution index (U). Square index (U) value of the content of chemical elements are divided into weakly contaminated, heavily soiled and extremely polluted landscapes (Dzhanaleyeva et al., 2017). On the basis of the functional zoning drawn landscape-geochemical map of 1:10 ooo scale (Figure 5).

With a geoecological view of recreation, we propose to use the idea of technogenic reservations proposed by Yu.S. Velikanov and A.N. Pavlov (Velikanov \& Pavlov, 2006). Man-made reservations - this is directly adjacent to the industrial facility, on which a system of certain prohibitive functions is carried out, aimed at limiting the values of 
maximum permissible concentrations (MPC) and other environmental parameters (Velikanov \& Pavlov, 2006). The man-made landscape created under such restrictions will prevent the spread of man-made changes related to the operation of the enterprise to territories beyond its regulated borders. Our proposed concept for creating technogenic reserves involves the creation of buffer zones, or environmental protection zones. This is a kind of border strip surrounding the technogenic reservation, beyond which an untouched natural landscape begins. Inside the buffer zones, it is recommended to carry out active environmental measures and strict monitoring control, which will allow urbanization of the natural landscape to be predictable and manageable. Thus, the creation of technogenic reserves can solve the problem of preserving the biodiversity of the region and preserving the natural appearance of recreational areas, reducing erosion processes.

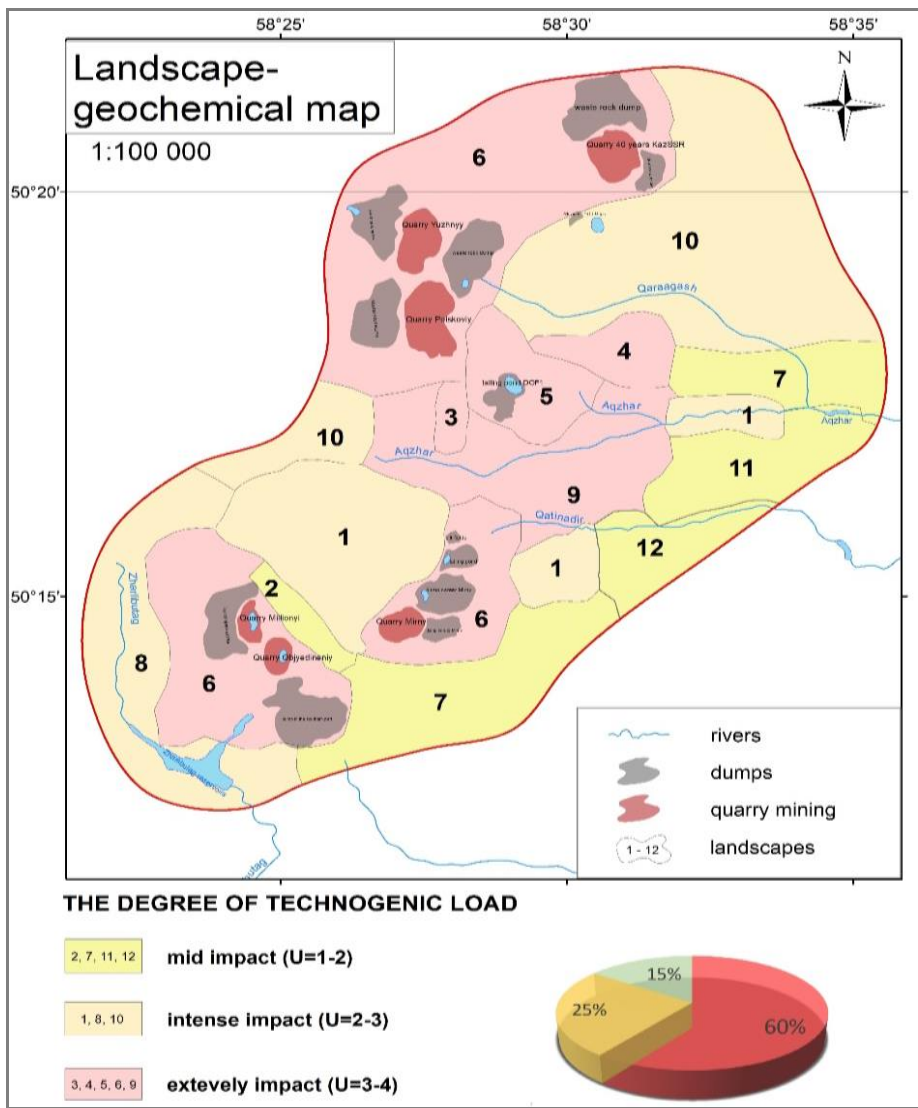

Figure 5. Landscape-geochemical map of the functional zoning of the Khromtau industrial site

\section{CONCLUSION}

As a result of the conducted researches it is possible to draw the following conclusions:

1. Unstable water regime of rivers, annual fluctuations in water availability caused significant changes hydromorphic landscapes. They endure various stages of change under the influence of technological processes and acrogenic changes.

2. Territory of Khromtau-Don industrial hub currently is an area of deeply modified nature where soil cover was radically changed and in reality represents a 
complex technogenic geosystem consisting of combination of various anthropogenic modifications of soils and unnatural soil-like formations.

3. Chemical pollution (mostly with heavy metals) is the more characteristic and environmentally important process of technogenic modification of studied soils. This process appears already on the stage of morphological description of quarries and spans more or less practically the whole territory of Khromtau-Don industrial hub.

4. Characteristic attributes of technogenic transformation of studied soils are sharp increase, in comparison to natural zonal soils, of degree of stereoscopic non-uniformity of soil cover and variability of soil properties appearing as a result of complex combination of natural self-organizational processes and various technogenic influences.

5 . The creation of technogenic reservations will make it possible to switch to a new environmental strategy for programming and managing technogenic landscapes in order to preserve recreational areas near the industrial center.

The developed model of technogenic geosystem and the cartographical model created on its basis in the ArcGIS10.1 program, allows to analyze one of the most important industrial regions of Western Kazakhstan for identification of the existing geo ecological systems and their high-quality differentiation. The factual information obtained during the research is considered as a preliminary guideline for a more objective and scientifically sound assessment of the ecological state of landscapes and the organization of environmental monitoring of territories.

\section{REFERENCES}

Badiali, F., Ilieş, D. C. \& Castaldini, D. (2018) A tale of a city, through its urban landscape and cultural heritage in the heart of Europe: The case study of Oradea city (Romania). Geojournal of Tourism and Geosites, no. 1, vol. 21, p. 88-102.

Berdenov, Z., G. (2014). Analysis of technogenic pollution of the environment of Aktobe region. Theoretical and practical problems of Geography. Materials of the international scientific conference, Astana, Kazakhstan, vol. 2, p. 121-126.

Berdenov, Z., G., Atasoy, E., Mendybayev, E., H., Ataeva, G. \& Wendt, J., A. (2016). Geosystems geoecological assessment of the basin of rivers for tourist valorization. Case study of Ilek river basin. Geojournal of Tourism and Geosites, no. 2, vol. 18, p. 187-195.

Berdenov, Z., Mendibaev, E., Salihov, T., Akhmedenov, K. \& Ataeva, G. (2017). Geoecological analysis of industrial cities: On the example of Aktobe agglomeration. Chemistry, no. 6, vol. 26, p. 890-902.

Berdenov, Zh., G. \& Dzhanaleeva G.M. (2015). Technogenic impact on the landscape geosystems for example Kargaly district of Aktobe region. European Conference on Innovations in Technical and Natural Sciences.Vienna, Austria, p. 74-79.

Dubrovskaya, S., A. (2012). Ecological and geochemical condition of soil and vegetation of the OrskNovotroitsky industrial hub. Bulletin of the Orenburg Scientific Center of the Ural Branch of the Russian Academy of Sciences. Orenburg, no. 4, p. 40-45.

Dzhanaleyeva, K., Mazhitova, G., Zhanguzhina, A., Berdenov, Zh., Bazarbayeva, T. \& Atasoy, E.. (2017). Technogenesis of geoecological systems of Northen Kazakhstan: progress, development and evolution. Chemistry: Bulgarian Journal of Science Education, no. 6, vol. 26, p. 903-921.

Gozner, M., Tătar, C.F., Stupariu, M. \& Măduta, F.M. (2017). Nature, Photography and Tourism in BihorVlădeasa Mountains (Romania). GeoJournal of Tourism and Geosites, Year X, Volume 20, OradeaGdansk, Romania-Poland, Editura Universităţii din Oradea.

Herman, G., Ilies, D. C., Gaceu, O., Ilies, A., Mester, C., Ilies, M., \& Dumitru, M. (2019). Some Considerations Concerning the Quality of Groundwater in the Natura 2000 Lunca Barcaului (Barcaului Meadow) Site, Romania. Journal of Environmental Protection and Ecology, 20(3). 1102-1109.

Ilies, D.C., Buhas, R., Ilies, M., Ilies, A., Gaceu, O., Pop, A.C., Marcu, F., Buhas, S.D., Gozner, M., \& Baias, S. (2018). Sport Activities and Leisure in Nature 2000 Protected Area - Red Valley, Romania. Journal of Environmental Protection and Ecology, 19, No 1, 367-372.

Ilieş, D., C., Baias, Ş., Buhaş, R., Ilieş, A., Herman, G., V., Gaceu, O., Dumbravă, R. \& Măduţa, F., M. (2017) Environmental education in protected areas. case study from Bihor County, Romania. Geojournal of Tourism and Geosites, no. 1, vol. 19, p. 126-132. 
Geochemical monitoring of industrial center for development of recreational areas (on the example of Khromtau-don industrial hub, Kazakhstan)

Jasinski, S., V. (2000). Environmental analysis of anthropogenic impacts on the catchment areas of small rivers. Izvestiya RAN, Geography Series, no. 4, p. 74-82.

Kabiyev, Y., S., Berdenov, Z., G., Dzhanaleeva, K., M., Atasoy, E. \& Wendt, J., A. (2018). Landscape ecological analysis of the modern delta of the Ural (Zhayik) river. Geojournal of Tourism and Geosites, no. 3, vol. 23, p. 644-655.

Kasimov, N., S. (1995). Ecogeochemistry urban landscapes. Moscow, p. 336.

Khomyakov, D., M. (2011). Soil degradation: causes, effects, ways to reduce and eliminate. Moscow, MSU, p. 272.

Koshim, A., G., Sergeeva, A., Umirzakova, Zh. \& Baydrakhmanova, G. (2015). Geoecological state of the Khromtau field and its mapping using Landsat satellite imagery at different times. Bulletin of KazNU. Geographical series, no. 2, vol. 41, p. 308-314.

Kotlyar, G., V., Golubev, V., K. \& Silantyev, V., V. (2013) General stratigraphic scale of the Perm system: current status. General stratigraphic scale of Russia: status and prospects of arrangement: collection of articles of the All-Russian Conference, Moscow, May 23-25, 2013, Moscow, Geological Institute of the Russian Academy of Sciences, p. 187-195.

Lincu, A., Ilieș, M., Ilieș, D.C., Herman, G.V., Baias, S., Gozner, M., Costea, M., \& Mihincău, D. (2018). Conservating the traditional cellars of Salacea, Bihor County, Romania. GeoJournal of Tourism and Geosites, 23(3), 748-758, https://doi.org/10.30892/gtg.23311-325.

Mendybayev, E., H., Atayeva, G., Berdenov, Zh. \& Atasoy, E. (2015). Geochemical researches of region soil with technogenic influence in terms of Borlinskiy region, West Kazakhstan. Oxidation Communications, no. 4, vol. 38, p. 1933-1941.

Moshkalev, A., G. (1998). Bookmarking of forest taxation and decoding test plots: a training manual, St. Petersburg, p. 80.

Pavleychik, V., M. (2015) Zhamanarkash tract is a natural heritage site. Nature (ISSN:o032-874X). no. 1, p. 154-159.

Perelman, A., I. \& Kasimov, N., S. (1999). Geochemistry of landscape, Moscow, MSU, p. 432.

Petrov, K., M. (1998). General ecology: the interaction of society and nature: Ouch. manual for schools. Chemistry, St. Petersburg, p. 352.

Ramazanova, N., Berdenov, Z., G., Ramazanov, S., Kazangapova, N., Romanova, S., Toksanbaeva, S. \& Wendt, J. (2019). Landscape-geochemical analysis of steppe zone basin Zhaiyk. News of the National Academy of Sciences of the Republic of Kazakhstan, Series of Geology and Technical Sciences, no. 436, vol. 4, p. 33-41.

Romocea, T., Oneț, A., Sabău, N.C., Oneț, C., Herman, G.V., \& Pantea, E. (2018). Change of the groundwater quality from industrial area Oradea, Romania, using Geographic Information Systems (GIS). Environmental Engineering \& Management Journal (EEMJ), 17(9), 2189-2199.

Shomanova, Zh., K., Safarov, R., Z., Auezhanova, A., Zhumakanova, A., S., Nosenko, Yu., G., Tleulesov, A., K. R. \& Larichkin, V., V. (2017). Study of Composite Catalysts Containing Sludge of Ferroalloy Production in the Process of Cyclohexane Oxidation. News of the National Academy of Sciences of the Republic of Kazakhstan, Series of Chemistry and Technology, no. 6, vol. 426, p. 55-61.

Shomanova, Zh., K., Safarov, R., Z., Zhumakanova, A., S., Nosenko, Y., G., Zhanibekova, A., T., Shapekova, N., L. \& Lorant, D. (2018). Electron microscopy surface study of catalysts based on ferroalloy production waste. News of the National Academy of Sciences of the Republic of Kazakhstan, Series of Chemistry and Technology, no. 6, vol. 432, p. 79-86.

Smirnov, N.T. (1979). Bookmarking sample plots: Guidelines for students of the Forestry Department, Ussuriysk, p. 78.

Stroganova, M., P., Myagkova, A., D. \& Prokofieva, T., V. (1997). Soil science. Moscow, MSU, vol. 1, p. $234-275$.

Theng, S., Qiong, X., Ilies, D. \& Dehoorne, O. (2014) Sustainable tourism and ecotourism: Experiences in the lesser Antilles. Advances in Intelligent Systems and Computing, vol. 254, p. 433-445.

Ungureanu, M., Dragota, C., Ilies, D., C., Josan, I. \& Gaceu, O. (2015) Climatic and bioclimatic touristic potential of padis karst plateau of the bihor mountains. Journal of Environmental Protection and Ecology, no. 4, vol. 16, p. 1553-1559.

Vaganova, O. \& Kovalchuk, O., A. (2012). Assessment of anthropogenic impacts on the landscape and hydrological systems. Geography and natural resources, no. 3, p. 151-156.

Velikanov, Yu., S. \& Pavlov, A., N. (2006) EIA is not a spell, but a path to survival. Oil of Russia, no. 5, p. 30-33.

Yeprintsev, S., A., Shekoyan, S. V., Lepeshkina, L., A., Voronin, A. A. \& Klevtsova, M.A. (2019) Technologies for creating geographic information resources for monitoring the socio-ecological conditions of cities. IOP Conference Series: Materials science and engineering, no. 1, vol. 582, p. 12.

*** Program for the development of single-industry towns for 2012-2020, approved by Resolution of the Government of the Republic of Kazakhstan dated May 25, 2012 No. 683. Electronic resource: https://online.zakon.kz/Document/?doc_id=31203906\#pos=0;42 (Date of appeal 10.09.2019).

*** GOST ISO 22036-2014. Soil quality. Determination of trace elements in soil extracts using atomic-emission spectrometry of inductively coupled plasma (ICP-AES).

*** Technical report. (2017). Environmental Impact Assessment (EIA) for the working draft "Construction of a stationary universal line for the technical control of cars and trucks, buses and road trains with an axle load of up to 10 tons. Asia consult LLP, Aktobe, Kazakhstan. 